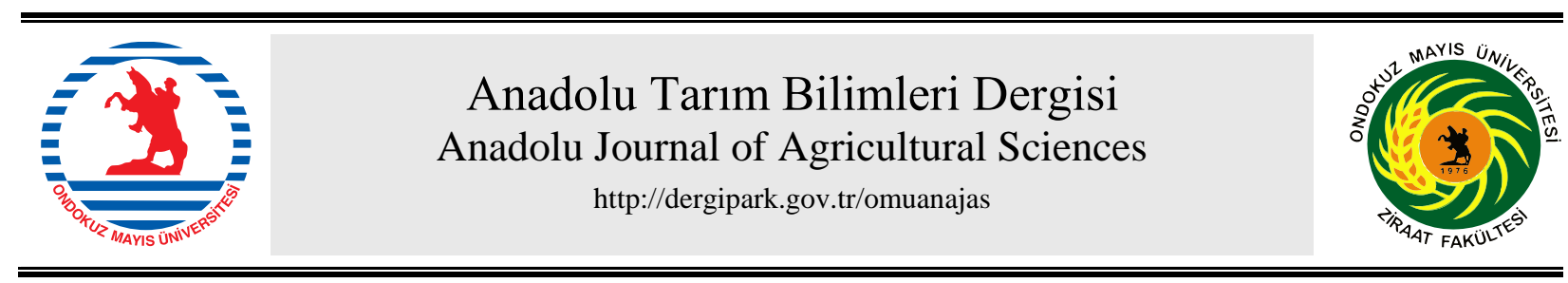

\title{
Araştırma/Research
}

Anadolu Tarım Bilim. Derg./Anadolu J Agr Sci, 35 (2020)

ISSN: 1308-8750 (Print) 1308-8769 (Online) doi: 10.7161/omuanajas.739004

\section{Kırsal ve Kentsel Alanda Bilgi ve İletişim Teknolojilerinin Kullanımı: Ankara Örneği}

\author{
Derya Gül ${ }^{\mathrm{a}}$, $\odot$ Kürşat Demiryürek ${ }^{\mathrm{a} *}$ \\ ${ }^{a}$ Ondokuz Mayıs Üniversitesi, Ziraat Fakültesi, Tarım Ekonomisi Bölümü, Samsun, Türkiye
}

*Sorumlu yazar/corresponding author: kursatd@omu.edu.tr

Geliş/Received 17/05/2020 Kabul/Accepted 16/07/2020

\begin{abstract}
ÖZET
$\mathrm{Bu}$ çalışma Ankara ili özelinde kırsal kesimde Bilgi ve İletişim Teknolojilerinin (BİT) kullanımının kentsel nüfusa göre farklılıklarını araştırmak amacı ile 2018 ve 2019 yıllarında yürütülmüştür. Çalışma, kentsel ve kırsal alanda yaşayan nüfusun BİT kullanımı açısından farklılık teşkil edip etmediğini belirlemesi, böylece gelecekte özellikle kırsal bölgelerin gelişiminde izlenebilecek BİT stratejilerinin temelini oluşturan özgün bir araştırma olması açısından önemlidir. Çalışmada gayeli örnekleme yöntemine göre seçilen kırsal alanda yaşayan 50 kadın ve 50 erkek ile kentsel alanda yaşayan 50 kadın ve 50 erkek olmak üzere toplam 200 deneğe anket uygulanmıştır. Veriler SPSS istatistik paket programı kullanılarak analiz edilmiştir. Analizler ki-kare $(\chi 2)$ istatistik testi ile değişkenler arasındaki farklıkları belirlemek için uygulanmıştır. Değerlendirme sonucunda kırsal ve kentsel alanlarda kadın ve erkekler arasında eğitim, çalışma durumu ve gelir farklılığının yanı sıra BİT araçlarının tipleri ve kullanım amaçları açısından anlamlı farklılıklar tespit edilmiştir. Sonuç olarak kırsal kesimde yaşayan kadın nüfusunun kentsel alanda yaşayan kadınlara göre daha düşük seviyede BİT kullandıkları belirlenmiştir. Özellikle kırsal kesimde internet alış-veriş ve finansal mobil uygulamalarının yaygınlaştırılması için kırsal kesim nüfusun özelliklerini dikkate alacak şekilde BİT güvenliği algısının arttırılması önerilebilir.

Information and Communication Technologies Use in the Rural and Urban Areas: The Case of Ankara, Turkey
\end{abstract}

\section{ABSTRACT}

This study was conducted to analyze the differences in the use of Information and Communication Technologies (ICT) between rural and urban people in Ankara. The study is particularly important as it is an original research that lays down the groundwork for developing future ICT strategies for rural development by determining the differences in ICT use between rural and urban man and woman population. In this study a total of 200 respondents (50 men and women from rural areas and 50 men and women from urban areas) were selected with purposeful sampling and applied face to face interviews. Data collected were analyzed with SPSS statistical analysis software for both personal and gender factors. Khi-squire ( $\chi^{2}$ ) analyses were made to reveal the differences among variables. The results showed that there were significant differences between gender and location (rural versus urban) in terms of education, income and employment status in addition to preferred ICT tools and their usage. Evaluation of the results revealed that the rural women utilized ICT less than those who live in urban areas. It can be suggested that increasing positive attitudes towards ICT use among rural population and ensuring perception towards internet security considering rural people's chracteristics would increase the adoption and diffusion of ICT such as internet sales and fintech applications.
Anahtar Sözcükler: Bilgi ve İletişim Teknolojileri (BİT) Köy-Kent Ayrımı Medya Okuryazarlığ1 Tarımsal Yayım Kirsal Kadın

Keywords: Information and Communication Technologies (ICT) Rural and Urban Disparity Rural Women Agricultural Extension 


\section{Giriş}

Günümüzde kullanımı hızla yaygınlaşan teknolojilerin başında bilgi ve iletişim teknolojileri (BİT) gelmektedir. Henüz 10-15 yıl öncesine kadar ancak bir bilgisayar aracıllı̆ı ile gerçekleştirilebilen görüntülü görüşme veya çevrim içi alışveriş gibi faaliyetler 2010'lardan itibaren cep telefonlarına kadar ulaşmış, üstelik Türkiye'nin hemen her yerinde son derece hızlı olarak gerçekleştirilebilecek duruma gelmiş̧lerdir.

Bununla birlikte, her ne kadar şehirde yaşayan nüfusun bu tür teknolojik gelişmelere uyum sağlaması oldukça hızlı olsa da tarihsel veri ve gözlemler kırsal nüfusa bu tür teknolojik yeniliklerin çok daha geç ulaștıklarını ve daha uzun bir zaman diliminde benimsendiklerini göstermektedir (Demiryürek, 1993; Abacı ve Demiryürek, 2015; Demiryürek ve Atsan, 2015).

Diğer yandan, gerek kırsal gerek kentsel alanda yaşayanlar arasında teknolojik yeniliklerin benimsenmesi açısından cinsiyetler arasında bir farklılık olduğu da bilinmektedir. Dünyada olduğu gibi Türkiye'de de kadınların teknolojiyi erkeklere göre daha geç benimsedikleri ve daha kısıtlı amaçlarla kullandıkları da belirlenmiştir. Ancak bu olgunun nedenlerine dair kırsal alanda detaylı araştırma sayısı sinırlıdır (Rogers, 1993; Cinemre ve Demiryürek, 2005; Demiryürek, 2015; Abacı ve Demiryürek, 2015).

Özellikle tarımsal üretim ve verimliliğin artışına şiddetle ihtiyaç duyduğu son dönemde BİT'in etkin kullanımı önemli bir fark yaratabilir. Kırsal kesimde üretimin belkemiğini oluşturan kadın nüfusunun BİT'i ne derece etkin kullanabildiklerini, hangi nedenlerle kullanamadıklarını belirlemek ve bu konuda önlemler almak ülke ekonomisi ve tarımsal kalkınma açısından önemlidir. Kadınların BİT araçlarının sağladığı olanaklar konusunda farkındalıklarını artırmak onların girişimcilik kapasitelerini geliştirmelerini sağlayabilecektir. Öte yandan medya okur yazarlık becerilerini arttırmak da kadınların pazara yönelik üretim yapmaları ve daha geniş kitlelere bu ürünleri pazarlamalarına ve dolayısıyla gelirlerini artırmalarına yardımc1 olabilecektir.

Bu nedenlerle Türkiye'de, özellikle kırsal kesimde kadın nüfusunun BİT kullanımına yönelik alan araştırması yapılması gerektiği ortaya çıkmıştır. Literatüre bakıldığında bu konuda belirgin bir eksiklik göze çarpmaktadır. Türkiye'de kadın nüfusu ile ilgili yapılan araştırmalarda ağırlıklı olarak kadının çalışma hayatındaki yeri konulu çalışmalar bulunmaktadır. Kırsal alanda yapılan araştırmalarda ise genellikle çiftçiler dikkate alınmış̧ır. Kırsal kesim ile kentsel alanlarda yaşayan kadın ve erkeklerin BİT kullanımı konusundaki farklılıklarını ortaya koyan güncel çalışmaların sayısı ise çok sınırlıdır. Bu nedenle yüksek lisans tezinden (Gül, 2019) çıkarılan bu araştırmanın kırsal alanda hem kadın hem de erkek nüfusunun BİT kullanımını ele alan ve kent nüfusu ile karşılaştırmasını gerçekleştiren özgün bir çalışma olduğu söylenebilir.

Saha çalışmaları hem oldukça yoğun bir kent nüfusu olan, hem de tarım ile geçimini sağlayan kırsal nüfusa sahip olan, nüfus açısından Türkiye'nin ikinci büyük kenti ve başkent olma özelliğini taşıyan Ankara şehir merkezi ve çevre ilçelerindeki köyler ile kırsal mahallelerde gerçekleştirilmiştir. Çalışma kapsamında hem genel olarak kır ve kent nüfusunun, hem de her iki alanda yaşayan kadınların birbirleri ile temel sosyoekonomik ve BİT kullanımı açısından farklılıkları irdelenmiştir.

Araştırmada Ankara ili kırsal ve kentsel alanında ikamet eden erkek ve kadın nüfusunun BİT kullanım durumları demografik bilgiler eşliğinde incelenerek temel olarak yaşanan bölge ve cinsiyetin BíT kullanım durumuna etkileri araştırılmıştır.

Ayrıca, kırsal kesim nüfusuna finansal, teknolojik veya bilgi açısından fayda sağlayabilecek BİT'in ne kadar yaygın ve hangi amaçlarla kullanıldığını ve bu kullanım eğilimlerinin kent nüfusu ile farklılıklarını bu araştırma belirlemeyi amaçlamaktadır.

\section{Kuramsal Temeller}

\subsection{Bilgi ve Illetişim Teknolojileri}

Bilgi ve iletişim teknolojileri (BİT) kavramı 21. yüzyılın ilk çeyreği itibariyle farklı kişi ve çevreler tarafindan farklı şekil ve kapsamlarda algilanabilmektedir. Bununla birlikte UNESCO tarafından yapılan bir tanım oldukça açıklayıcı ve nettir. Buna göre, "Bilgi ve iletişim teknolojileri, bilgiyi oluşturma, depolama, iletme ve paylaşma amaciyla kullanılan çok çeşitli teknolojik araçlar ve kaynaklara verilen isimdir. $\mathrm{Bu}$ teknolojik araç ve kaynaklar bilgisayarları, interneti (web siteleri, bloglar ve epostalar), canlı yayın teknolojileri (radyo, televizyon ve web üzerinden yayın yapma), kayıtlı yayın teknolojileri (podcastler, ses ve görüntü oynatıcılar ve depolama cihazları) ve telefon sistemlerini (sabit veya mobil, uydu, video konferans, vb.) içermektedir.” (UNESCO, 2019).

\subsection{BİT Kullanımında Cinsiyet Farklllıkları}

BİT araçlarının kullanımında erkekler ve kadınlar arasında belirgin farklılıklar göze çarpmaktadır. Özellikle Türkiye'de neredeyse tüm yaş gruplarında kadın nüfusunun erkek nüfusuna göre BİT'i benimseme ve kullanma oranının daha düşük olduğu dikkati çekmektedir. Her ne kadar yıllar bazında her iki 
cinsiyetin de BİT kullanımında artış görülse de yaş arttıkça cinsiyetler arası BITT kullanımı farkının arttı̆̆ bilinmektedir (TÜIK, 2019a). Bir başka deyişle, genç nüfusta kadın ve erkeklerin BİT kullanımı neredeyse eşit olmakla birlikte, ilerleyen yaşla birlikte BİT kullanımı kadınlarda erkeklere göre daha hızlı bir düşüş sergilemektedir.

\subsection{BİT Kullanımında Bölgesel Unsurlar}

Genel olarak bakıldığında kırsal alanlar tarımsal faaliyetler ile geleneksel yaşam ve üretim ilişsilerinin baskın olduğu, hem toplumsal hem de ekonomik değişimin kentlere göre yavaş seyrettiğii, toplumsal iş bölümünün zayıf, yüz yüze ilişkilerin egemen olduğu sosyal çevreyi ifade etmektedir (Anonim, 2018a). Günümüzde, Türkiye'de mekânsal istatistik üretimine esas kırsal alan tanımlarında, nüfus eşiği ve idari statü ölçütlerini esas alan iki farklı tanım kullanılmaktadır. TÜİK (2018) tarafindan nüfus eşiği ölçütüne göre (kırkent tanımı), nüfusu 20.001 ve üzeri olan yerleşim yerleri "kent", 20.000 ve daha düşük nüfusa sahip olanlar ise "kır" olarak tanımlanmaktadır.

Kırsal alanlarda genel olarak BİT erişimi ve kullanımında zorluklar yaşandığı bilinmektedir. Bu yalnızca Türkiye'de değil dünya çapında gözlemlenmiş ve belgelenmiş bir durumdur. Gelişmiş ve gelişmekte olan ülkelerde bile devletin de özel kuruluşların da kırsal bölgelerde gerekli bilgi teknolojileri altyapısını yaygınlaştırmak için çaba harcamalarına rağmen halen kırsal bölgelerde BİT erişimi kentsel alanların gerisindedir (Demiryürek, 1993; Demiryürek ve Atsan, 2015; Abacı ve Demiryürek, 2015; Salemink vd, 2015).

\subsection{Türkiye’de cinsiyet faktörü ve bilgi teknolojilerine dair çalışmalar}

Türkiye'de cinsiyet ile bilgi teknolojileri kullanımı arasındaki ilişkiyi araştıran çalışma sayısı yok denecek kadar azdır. Her ne kadar bazı araștırmalar ile hizmet öncesi öğretmen adaylarının bilgi teknolojileri kullanımı niyetlerini ölçme (Ursavaş, 2015), internet kullanımı ile ilgili bir Likert tipi tutum ölçeği geliştirme (Tavşancil ve Keser, 2002) ve ergenlerde aşırı internet kullanımının nedenleri ve sonuçları (Akar, 2015), çiftçilerin iletişim davranışları (Demiryürek, 1993; Çukur, 2013) üzerine çalışmalar yapılmışsa da hiç biri etkin şekilde bilgi teknolojilerinin benimsenme ve kullanımını cinsiyet bazında incelememektedir.

$\mathrm{Bu}$ durumun muhtemel nedenleri arasında Türkiye'de bu konuda elde edilen sonuçların toplumun ilgili kısmı ile uyuşup uyuşmadığını belirlemek üzere kullanılabilecek yetkin istatistiklerin bulunmaması düşünülebilir. Tıpkı kırsal/kentsel ayrımında olduğu gibi, bilgi teknolojileri kullanımı konusundaki istatistikler son derece genel seviyede ve yetersizdir.
Cinsiyete göre oluşturulmuş istatistikler en fazla yaş grupları ve cinsiyet bilgisini içermektedir.

\section{Materyal ve Yöntem}

Çalışma konusu Ankara örneğinde kentsel ve kırsal alan nüfusunun BİT kullanım alışkanlıklarını ölçmektir. Her ne kadar büyük şehirli belediyelerde kırsal ve kentsel nüfusunu belirlenmesi güç olsa da (Özçağlar, 2016) bu çalışma kapsamında nüfus yerleşim bilgileri ve cinsiyet ayrımları için TÜİK istatistiklerinden yararlanılmıştır.

Veri toplama amaciyla gayeli örnekleme yöntemine göre Ankara ilinin kırsal ve kentsel kesiminde yaşayan 50 'şer erkek ve 50'şer kadın olmak üzere toplam 200 kişiye çoktan seçmeli anket uygulanmıştır. Anketlere verilen yanıtların kâğıt ortamında kaydedilmeleri, ayrıca araştırıcının kendisinin katılımcı ile yüz yüze görüşmesi ve soruları sözlü olarak sorup verilen yanttları işaretlemesi şeklinde gerçekleştirilmeleri uygun görülmüştür. Anketler yanıtlanırken katılımcılardan herhangi bir özlük bilgisi alınmamakta, ancak demografik bilgiler toplanmaktadır. Ankette şehirde yaşayan kadın ve kırsalda yaşayan erkek nüfusu cinsiyet ve yerleşim alanı açısından kontrol grupları, kırsalda yaşayan kadın nüfusu ise deney grubu olarak belirlenmişlerdir.

Örnekleme büyüklüğünü belirlemek için çalışmanın gerçekleştirildiği Ankara ilinin nüfusu esas alınmıştır. 2018 y1l itibariyle Ankara nüfusunun 5503,985 kişi olduğu belirlenmiştir (TÜIK, 2019b). Ayrıca araştırmanın hata payı $\% 7$, güven aralı̆g ise $\% 95$ olarak belirlenmiştir. Bu bilgiler ışığında gayeli örnekleme ile 200 kişilik bir örneklem büyüklüğü uygun görülmüştür.

Çalışmanın temeli kırsal ve kentsel alan ayrımına dayandığı için kentsel alan sınırları Google Maps uydu fotoğraflarından yararlanılmıştır. Kentsel ve kırsal alan konusunda net bilgi sağlanamadığı için TÜIKK sisteminden anketlerin gerçekleştirileceği alan seçimi konusunda verim alınamamıştır. Bunun yerine Google Maps kullanılarak Ankara ilinin uydu görüntüleri incelenmiş, yakınlarında işlenmiş tarımsal alan bulunan yerleşim merkezleri tespit edilmişlerdir. $\mathrm{Bu}$ yerleşim merkezlerinden kırsal alan olarak belirlenen mahallelerin nüfus verileri TÜIK'ten kontrol edilerek nüfusları birbirine yakın olan, batıda E-5 karayoluna yakın olan Beylikköprü, kuzeyde de herhangi bir ticari rotaya yakın olmayan Sarıoba uygulama sahası olarak belirlenmişlerdir.

Yine TÜIK veya Nüfus ve Vatandaşlık İdaresi üzerinden yerleşim merkezlerine ait cinsiyet dağılım bilgilerine ulaşılamamıştır. Anket sahası olarak seçilen yerleşim merkezlerinin cinsiyet dağılım verilerine 
erişilebilen 2013 yılı oranları incelenmiş ve cinsiyet dağılımının yaklaşık \%50 erkek \%50 kadın olduğu tespit edilmiştir. $\mathrm{Bu}$ veriler esas alınarak ankette

Saha çalışması gerçekleştirmeden önce incelenen konular ve araştırma soruları esas alınarak belirlenen ve bireysel merak, gözlem ve deneyimle desteklenen, çalışmaya ait alternatif hipotezler şunlardır:

H1: Kırsal alanda yaşayan nüfusta BİT kullanımı kentsel alana göre daha azdır.

H2: Kırsal alanda yaşayan kadın nüfusunun BİT kullanımı erkek nüfusuna göre daha düşüktür.

H3: Kırsal alanda yaşayan kadın nüfusunun BİT kullanımı kentsel alanda yaşayan kadın nüfusuna göre daha düşüktür.

H4: Kentsel alanda yaşayan erkek nüfusunun BİT kullanımı kadın nüfusunun BİT kullanımına göre daha yüksektir.

Belirtilen hipotezleri etkileyen faktörler, bir diğer ifadeyle bağımsız değişkenler yaşanan alan, cinsiyet, yaş, eğitim seviyesi ve ekonomik durum olarak öngörülmüşlerdir. BİT kullanım sıklı̆ğ ve kullanım amaçları ise bağımlı değişkenlerdir. Değişkenler arasındaki farklılıkları ortaya koymak amaciyla SPSS istatistik paket programına aktarılan verilere uygun olan parametrik olmayan ki-kare $(\chi 2)$ testi uygulanmıştır. öngörülen eşit oranda erkek ve kadına anket uygulanması varsayımının doğru olduğu sonucuna varılmıştır.

\section{Bulgular ve Tartışma}

Gerçekleştirilen anketlerden elde edilen veriler işlenmiş ve istatistiksel olarak değerlendirilmişlerdir. BİT kullanımı konusunda kırsal ve kentsel alan nüfusu arasında bazı farklılıklar bulunduğu gözlemlenmiştir. Bazı önemli demografik değişkenlere ait bulgular aşağıda sunulmuştur.

\section{1 Ĕgitim}

Eğitim, tanım olarak, bu amaca yönelik olarak kurulan kurumlar vasıtasıyla kişilere hayat için gerekli olan bilgi ve becerilerin sistematik bir şekilde kazandırılmasıdır. Genel olarak eğitim düzeyi yüksek toplumlarda bireylerin hayata daha hazırlıklı ve zorluklarla baş etmede daha becerikli oldukları söylenebilir. Ankete katılan kişilerin eğitim durumlarının yaşadıkları yerleşim alanlarına göre dağılımları incelenmiş ve Çizelge 1'de verilmiştir.

Çizelge 1. Ankete katılan kişilerin eğitim durumlarının yaşadıkları yerleşim alanlarına göre dağılımı

Table 1. Distribution of respondents according to their level of formal eduction with place to live

Eğitim Durumu

\begin{tabular}{|c|c|c|c|c|c|c|c|}
\hline \multirow{2}{*}{\multicolumn{2}{|c|}{ Yerleşim Alanı }} & & & & & & \multirow[b]{2}{*}{ Toplam } \\
\hline & & $\begin{array}{l}\text { Okuryazar } \\
\text { ilkokul terk }\end{array}$ & İlkokul & Ortaokul & Lise & $\begin{array}{l}\text { Lisans ve } \\
\text { üzeri }\end{array}$ & \\
\hline & & n (\%) & n (\%) & n (\%) & n (\%) & n (\%) & n (\%) \\
\hline Kentsel & & $0(0)$ & $0(0)$ & $0(0)$ & $42(42)$ & $58(58)$ & $100(100)$ \\
\hline Kirsal & & $32(32)$ & $50(50)$ & $18(18)$ & $0(0)$ & $0(0)$ & $100(100)$ \\
\hline Toplam & & $32(16)$ & $50(25)$ & $18(9)$ & $42(21)$ & 58 (29) & 200 (100) \\
\hline$\chi^{2}: 200.00$ & $\mathrm{P}<0.001$ & & & & & & \\
\hline
\end{tabular}

Çizelge 1 incelendiğinde kentsel ve kırsal alan arasında büyük bir eğitim farklılığı göze çarpmaktadır. Kentsel alanda en düşük eğitim seviyesi lise iken (\%42.0) kırsal alanda en yüksek eğitim seviyesinin ortaokul olduğu ayrıca kırsalda yaşayan kişilerin \%50.0'sinin ilkokul mezunu oldukları görülmektedir. Eğitim durumunun yaşanan bölgeye göre farkl1l1k gösterdiği ve bunun istatistiki olarak anlamlı olduğu tespit edilmiştir.

Arıkan'a (1988) göre 1980 yılı nüfus sayımı sonuçlarına göre kırsal kesimde yaşayan kadınların $\% 61.5$ 'i okur yazar değildir. Toplam nüfus içinde okur yazar olmayan kadın nüfusu ise aynı sayıma göre \%38.1'dir. Özaydınlık (2014) ise 2011 yılı itibariyle genel nüfus içinde okur yazar olmayan kadın oranının \%7.8 olduğunu ifade etmektedir. Dolayısıyla genelde okuryazarlığın artması söz konusudur. Ancak kırsal kesime bakıldığında TBMM komisyon raporuna (Anonim, 2018b) göre kadın nüfusunun halen daha \%15'i okuryazar değildir. Oysa bu araştırmada Ankara çevresindeki kırsal alanda yaşayan kadın nüfusunda okuryazar olmayan kimseye rastlanmamıştır. Bununla birlikte diğer iller ve bölgelerde yaşayan kadın nüfusunda daha yüksek okuryazar olmama oranları söz konusu olabilir. Özaydınlık (2014)'ın da belirttiği gibi, okuryazarlık oranı Türkiye'nin batısından doğusuna doğru gittikçe düşmekte ve her zaman kadınlarda erkeklere göre daha yüksek olmaktadır. 


\subsection{Yerleşim Alanı ve Çalışma Durumu}

Yerleşim alanı, genel kapsamda bireylerin barındıkları bölgeyi ifade etmektedir. Kentsel alan nüfus yoğunluğunun yüksek olduğu ve nüfusun çoğunun tarım ve hayvancılık dıșı faaliyetler ile geçimlerini sağladıkları bölgelerdir. Kırsal alan ise düşük nüfus yoğunluklu ve çoğunlukla tarım ve hayvancılık faaliyetleri ile halkın geçimini sağladığı bölgelerdir. Ankete katılan kişilerin çalışma durumlarının yaşadıkları yerleşim alanlarına göre dağılımları incelenmiş ve Çizelge 4.2 'de verilmiştir.

Çizelge 2. Ankete katılan kişilerin çalışma durumlarının yaşadıkları yerleşim alanlarına göre dağılımı Table 2. Distribution of respondents according to their employment status with place to live

Çalışma Durumu

\begin{tabular}{|c|c|c|c|c|c|c|c|c|c|}
\hline Yerleşim Alanı & 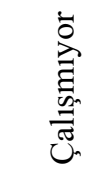 & 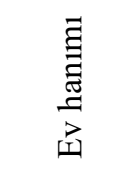 & $\begin{array}{l}\overline{0} \\
\overline{0} \\
: 50 \\
: 0\end{array}$ & 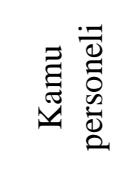 & 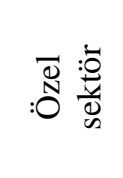 & 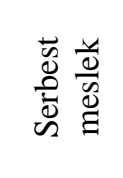 & 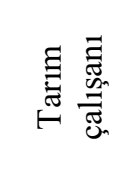 & 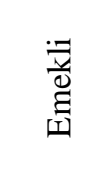 & Toplam \\
\hline & $\mathrm{n}(\%)$ & n (\%) & $\mathrm{n}(\%)$ & $\mathrm{n}(\%)$ & n (\%) & $\mathrm{n}(\%)$ & $\mathrm{n}(\%)$ & $\mathrm{n}(\%)$ & $\mathrm{n}(\%)$ \\
\hline Kent & $7(7)$ & $5(5)$ & $12(12)$ & $26(26)$ & $22(22)$ & $22(22)$ & $0(0)$ & $6(6)$ & $100(100)$ \\
\hline Kirsal & $5(5)$ & $31(31)$ & $0(0)$ & $0(0)$ & $15(15)$ & $0(0)$ & $47(47)$ & $2(2)$ & $100(100)$ \\
\hline Toplam & $12(6)$ & $36(18)$ & $12(6)$ & $26(13)$ & 37 (19) & $22(11)$ & $47(24)$ & $8(4)$ & 200 (100) \\
\hline
\end{tabular}

$\chi^{2}: 129.44 \quad \mathrm{P}<0.001$

Çizelge 2 incelendiğinde ankete katılan kişilerin çalışma durumlarının yaşadıkları yerleşim alanlarına göre farklılık gösterdiği ve bunun istatistiksel olarak anlamlı olduğu belirlenmiştir $(\mathrm{P}<0,001)$. Kırsal kesimdeki nüfusun neredeyse yarısı tarım çalışanıdır. Bunun dışında kalan kesim ağırlıklı olarak ev hanımlarında oluşmaktadır. Kentsel alanda ise kamu personeli olarak çalışan \%26'lık bir kesimi her biri \%22 ile özel sektör ve serbest meslek çalışanları takip etmektedir. Çalıșma durumunun yaşanan bölgeye göre farklılık gösterdiği söylenebilir.

Arıkan (1988) kırsal kesimde yaşayan kadınların toplam kırsal kesim işgücü içindeki paylarının \%50$\% 80$ arasında değiştiğini ifade etmiştir.

Ancak Peker ve Kubar (2012)'a göre 2010 yılı itibariyle kırsal kesimde kadınların işgücüne katılım oranı \%36.3'tür. Bu farklılı̆̆ın nedenleri arasında yıllar içinde köyden kente göçün hızlanması etkin olsa da giderek artan kırsal kadın nüfusu eğitim oranları ve kadın girişimci sayısındaki artışın da payı olduğu kesindir. Diğer yandan, yine Peker ve Kubar (2012) tarafından belirtilmiş olan kırsal kesim tarım çalışanı oranı olan \%54 rakamı ile bu çalışmada tespit edilen $\% 47$ rakamı birbirine yakındır. \%7'lik farkın kadınların aile işçiliğinden ücretli çalışan veya girişimciliğe yönelmesi, kırsaldan kente göç veya zaman içinde değișen kırsal/kentsel alan ayrımından kaynaklanması mümkündür.

\subsection{Yerleşim Alanı ve Gelir Durumu}

Gelir durumu genel olarak bireye veya haneye aylik olarak düzenli olarak girişi gerçekleşen nakit para miktarını ifade etmektedir.

Aylık ücretli çalışan kesim için bu rakamı net belirlemek kolay olsa da serbest meslek erbabı olan kişilerin işlerinin piyasa koşullarındaki dalgalanmalardan etkilenmeleri veya tarımla geçimini sağlayan kesimin faaliyetlerinin mevsimlere bağl1 olması nedeniyle gelir düzensizliği söz konusudur.

$\mathrm{Bu}$ nedenle aylık geliri sabit olmayan kesimin gelir durumu net bir karşılaştırma yapabilmek amacıyla yıllık net gelirin on ikiye bölünmesi ile elde edilmiş ve katılımcılardan hesaplanan rakamın gerçeğe uygunluğu konusunda onay alınmıştır.

Bilgi ve iletişim teknolojisi araçları gerek satın alma, gerekse hizmet verdikleri ekonomik ömür boyunca sahiplerine maddi yük getirebilirler. Genellikle de gelir seviyesi yüksek olan bireylerin BİT'e daha fazla harcama yapacakları düşünülebilir. Ankete katılan kişilerin gelir durumlarının yaşadıkları yerleşim alanlarına göre dağılımları incelenmiş ve Çizelge 3 'de verilmiștir. 
Çizelge 3. Ankete katılan kişilerin gelir durumlarının yaşadıkları yerleşim alanlarına göre dağılımı

Table 3. Distribution of respondents according to their income with place to live

\begin{tabular}{|c|c|c|c|c|c|}
\hline \multirow{3}{*}{ Yerleşim Alanı } & \multicolumn{4}{|c|}{ Gelir (TL) } & \multirow{2}{*}{ Toplam } \\
\hline & $1800-2500$ & $2501-5000$ & $5001-10000$ & $>10001$ & \\
\hline & n (\%) & n (\%) & n (\%) & n (\%) & n (\%) \\
\hline Kent & $21(21)$ & $54(54)$ & $24(24)$ & 1 (1) & $100(100)$ \\
\hline Kirsal & $56(56)$ & $44(44)$ & $0(0)$ & $0(0)$ & 100 (100) \\
\hline Toplam & 77 (38.5) & $98(49)$ & $24(12)$ & $1(0.5)$ & 200 (100) \\
\hline$\chi^{2}: 41.929$ & $\mathrm{p}<0.00$ & & & & \\
\hline
\end{tabular}

Ankete katılan kişilerin gelir durumlarının yaşadıkları yerleşim alanlarına göre farklılığ istatistiksel olarak anlamlı bulunmuştur $(\mathrm{P}<0,001)$. Kentsel alanda yaşayan nüfusun \%54'lük bir kısmı 2501-5000 TL aras1 gelire sahipken kırsal alanda bu gelire sahip olan kesim \%44'tür. Kırsal alanda yaşayan nüfusun \%56'l1k bir kısmı ancak 1800-2500 TL aras1 aylık net gelire sahiptir. Elde edilen bulgulara göre gelir durumunun yaşanan alana göre farklılık gösterdiği belirtilebilir. Kırsal nüfus için ortalama aylık gelir rakamı $2500 \mathrm{TL}$ iken kentsel alanda yaşayan nüfus için bu rakam 5000 TL'dir. Ulaş1labilen bilgilere göre 2016 yılında yıllık hane halkı fert geliri 19139 TL, dolayısıyla ortalama aylık 1600 TL civarındadır (Anonim, 2017b). Aynı yıl için asgari ücret rakamı ise net 1300 TL'dir (Anonim, 2017c). Buna göre 2016 yılı itibariyle kırsal kesim hane halk1 fert geliri asgari ücretin $\% 23$ kadar üzerindedir. Araştırma sonuçlarına göre ise 2019 yılında kırsal kesim ortalama hane halk1 fert geliri, 2019 yılı net asgari ücret rakamının \%20 kadar üzerindedir. Buna göre sonuçların doğrulandığı söylenebilir.

\subsection{Kullanılan BìT Araçları}

Kırsal ve kentsel alanlarda tercih edilen BİT araçlarının farklılık göstereceği öngörülmektedir. Bunun nedenleri arasında bazı BİT araçlarının ihtiyaç duyduğu fiber optik kablo gibi altyapı olanaklarının kırsal alanda çoğu zaman nadiren bulunması, ayrıca kentsel ve kırsal alanda günlük yaşamın farklı olması düşünülebilir.

Artık kanıksanmış olsalar da radyo ve televizyon gibi araçlar da BİT kapsamında yer alırlar (Almina, 2017; Anonim, 2017a).

Çizelge 4. Ankete katılan kişilerin bilgi ve iletişim teknolojileri kullanım durumlarının yaşadıkları yerleşim alanlarına göre dağılımı

Table 4. Distribution of respondents according to their use of Information and Communication Technologies with place to live

\begin{tabular}{|c|c|c|c|c|c|c|}
\hline \multirow{3}{*}{ BİT } & \multirow{3}{*}{$\begin{array}{l}\text { Yerleşim } \\
\text { Alanı }\end{array}$} & \multicolumn{2}{|c|}{ BİT Kullanma Durumu } & \multirow{2}{*}{ Toplam } & \multirow{3}{*}{$\chi^{2}$} & \multirow{3}{*}{$\mathrm{P}$} \\
\hline & & Hayır & Evet & & & \\
\hline & & $\mathrm{n}(\%)$ & $\mathrm{n}(\%)$ & $\mathrm{n}(\%)$ & & \\
\hline \multirow{3}{*}{ Radyo } & Kent & $71(71)$ & $29(29)$ & 100 (100) & \multirow{3}{*}{110.078} & \multirow{3}{*}{$<0.001$} \\
\hline & Kirsal & $0(0)$ & $100(100)$ & $100(100)$ & & \\
\hline & Toplam & $71(35.5)$ & $129(64.5)$ & $200(100)$ & & \\
\hline \multirow{3}{*}{$\mathrm{TV}$} & Kent & 19 (19) & $81(81)$ & $100(100)$ & \multirow{3}{*}{20.994} & \multirow{3}{*}{$<0.001$} \\
\hline & Kirsal & $0(0)$ & $100(100)$ & $100(100)$ & & \\
\hline & Toplam & $19(9.5)$ & $181(90.5)$ & $200(100)$ & & \\
\hline \multirow{3}{*}{ Ev telefonu } & Kent & $60(60)$ & $40(40)$ & $100(100)$ & \multirow{3}{*}{50.001} & \multirow{3}{*}{$<0.001$} \\
\hline & Kirsal & $100(100)$ & $0(0)$ & 100 (100) & & \\
\hline & Toplam & $160(80)$ & $40(20)$ & $200(100)$ & & \\
\hline \multirow{3}{*}{ Cep Telefonu } & Kent & $3(3)$ & 97 (97) & $100(100)$ & \multirow{3}{*}{3.046} & \multirow{3}{*}{0.081} \\
\hline & Kirsal & $0(0)$ & $100(100)$ & $100(100)$ & & \\
\hline & Toplam & $3(1.5)$ & 197 (98.5) & $200(100)$ & & \\
\hline \multirow{2}{*}{ Ak1llı telefon } & Kent & $3(3)$ & 97 (97) & $100(100)$ & \multirow{2}{*}{5.838} & \multirow{2}{*}{0.016} \\
\hline & Kirsal & $12(12)$ & $88(88)$ & $100(100)$ & & \\
\hline
\end{tabular}




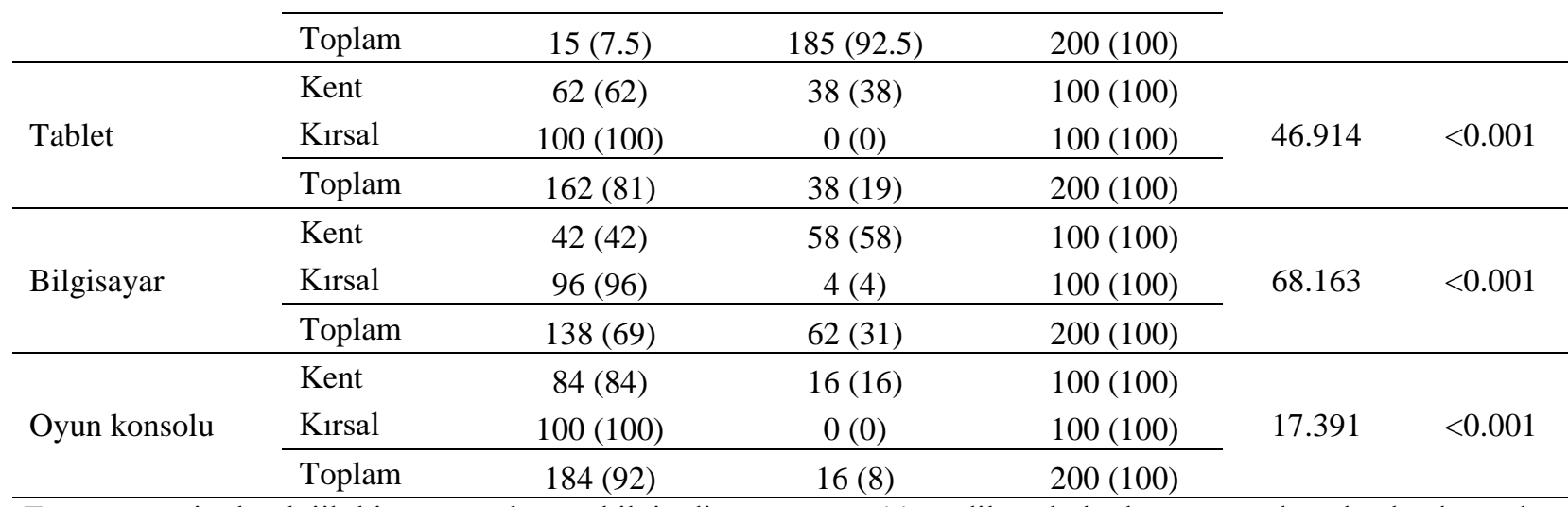

Tanım gereği teknolojik bir yapısı olan ve bilgi edinme ve paylaşma ve iletişim sağlama özelliğine sahip tüm araçları bu kapsamda ele almak mümkündür. Ancak internetin bulunması (Abbate, 2000) ve özellikle yaygınlaşması ile günümüzde BİT teknolojilerinin çoğu internete dayanmaktadır.

Araştırmanın kapsamı ve daha önce TÜIK tarafindan gerçekleştirilen araştırmalar esas alınarak incelenen BİT araçları radyo, televizyon, sabit telefon, cep telefonu, akillı telefon, tablet, bilgisayar ve oyun konsolu seçenekleri ile sınırlanmışlardır.

Ankete katılan kişilerin kullandıkları bilgi iletişim teknolojilerinin yaşadıkları yerleşim alanlarına göre dağılımları incelenmiş ve Çizelge 4'te verilmiştir. Yaşanılan bölgenin günlük kullanılan teknolojik cihazlar üzerine etkileri incelenmiş olup, radyo, televizyon, ev telefonu, akıllı telefon, tablet, bilgisayar ve oyun konsolu üzerine etkilerinin önemli olduğu $(\mathrm{P}<0,001)$ cep telefonu üzerine ise etkisinin önemli olmadığı belirlenmiştir $(\mathrm{P}>0,05)$.

\subsection{BITT Kullanım Alışkanlıkları}

Kentsel ve kırsal alanda yaşayan bireylerin BİT'i farklı amaçlar çerçevesinde kullanacakları öngörülmektedir. Yaşanan alanlar arasındaki günlük yaşam dinamikleri gereği, örneğin kentsel alanda yaşayan nüfusun ders çalışma amacıyla BİT'ten yararlanma oranının kırsal alanda yaşayan nüfusa kıyasla daha yüksek olacağı öngörülebilir.

Burada amaç kentsel ve kırsal alanda yaşamanın BİT kullanım alışkanlıklarını hangi yönde ve ne kadar etkilediğini belirleyebilmektir.

Ankete katılan kişilerin internet kullanım alışkanlıklarının yaşadıkları yerleşim alanlarına göre dağglımları incelenmiş ve Çizelge 5'de verilmiştir.

Bilgi ve iletişim teknolojilerini kullanım amaçlarının yaşanılan bölgeye göre farklılık durumu incelendiğinde kırsal ve kentsel alanda yaşamanın anlık mesajlaşma, video izleme ve diğer amaçlar doğrultusunda kullanımı açısından anlamlı bir fark oluşturmadığ 1 tespit edilmiştir $(\mathrm{P}>0,05)$.
Elde edilen bulgulara göre kırsal alanda radyo kullanımı \%100 iken kentsel alanda radyo kullanımının $\% 29$ olduğu belirlenmiştir.

Kırsal alanda yaşayanların \%100'ü televizyon izlerken kentsel alanda yaşayanların \%81'i televizyon izlememektedir. Kırsal alandaki kişilerin \%100'ü ev telefonu kullanmazken kentsel alanda yaşayanların \%40'1 ev telefonu kullanmaktadır.

Kırsal alanda yaşayan kişilerin akıllı telefon kullanımı kentsel alanda yaşayanlara göre daha düşük bulunmuştur. Tablet kullanımı incelendiğinde kırsal alanda tabletin hiç kullanılmadığı gözlemlenmişken kentsel alanda yaşayanların \%38'i tablet kullanmaktadır.

Yaşanılan bölgeye göre bilgisayar kullanımları incelendiğinde kentsel alanda yaşayanların \%58'i bilgisayar kullanırken kırsal alanda yaşayanların \%96'sı bilgisayar kullanmamaktadır.

Kentsel alanda yaşayan kişilerin \%16's1 oyun konsolu kullanırken kırsal alanda yaşayan kişilerin hiçbirinin oyun konsolu kullanmadığı belirlenmiştir.

Ancak güncel haber takibi, ders çalışma, sosyal medya takibi, müzik dinleme, oyun oynama, finansal işlemler ve alışveriş amaçlı kullanımlarda yaşanılan bölgeye göre anlamlı bir farklılık olduğu belirlenmiştir $(\mathrm{P}<0,05)$. Elde edilen bulgulara göre kentsel alanda yaşayan kişilerin $\% 54$ 'ü güncel haberleri takip etmek için interneti kullandıklarını bildirmişken kırsal alanda yaşayan kişilerin $\% 88$ 'i interneti günlük haberleri takip için kullanmaktadır. Kentsel alanda yaşayan kişilerin $\% 41$ 'i interneti ders çalışmak için kullandığını bildirmişken kırsal alanda yaşayan kişilerden hiç kimse ders çalışmak için interneti kullandığını bildirmemiştir. Kırsal alanda yaşayan kişilerin \%88'i interneti sosyal medyayı takip için kullanırken kentsel alanda yaşayan kişilerin \%52'si sosyal medyayı takip için interneti kullanmaktadır. Kentte yaşayan kişilerin \%61'i interneti müzik dinlemek için kullandığını bildirmişlerdir. Oyun için internet kullanımı kentsel alanda yaşayan kişilerde $\% 43$ olarak belirlenmiştir. Finansal işlemler için internet kullanımı kentsel alanda \%48 iken kırsal alanda hiç kullanılmamaktadır. 
Çizelge 5. Ankete katılan kişilerin internet kullanım alışkanlıklarının yaşadıkları yerleşim alanlarına göre bağımlılığı Table 5. Distribution of respondents according to their use of internet with place to live

\begin{tabular}{|c|c|c|c|c|c|c|}
\hline \multirow{3}{*}{ Alışkanlıklar } & \multirow{3}{*}{ Yerleşim Alanı } & \multicolumn{2}{|c|}{ Kullanım Durumu } & \multirow{2}{*}{ Toplam } & \multirow{2}{*}{$\chi^{2}$} & \multirow{2}{*}{$\mathrm{P}$} \\
\hline & & Hayır & Evet & & & \\
\hline & & n (\%) & n (\%) & n (\%) & & \\
\hline \multirow{3}{*}{ Güncel haber takip } & Kent & $46(46)$ & $54(54)$ & $100(100)$ & & \\
\hline & Kirsal & $12(12)$ & $88(88)$ & $100(100)$ & 28.072 & $<0.001$ \\
\hline & Toplam & $58(29)$ & $142(71)$ & $200(100)$ & & \\
\hline \multirow{3}{*}{ Ders çalışmak } & Kent & 59 (59) & $41(41)$ & $100(100)$ & & \\
\hline & Kirsal & $100(100)$ & $0(0)$ & $100(100)$ & 51.572 & $<0.001$ \\
\hline & Toplam & 159 (79.5) & $41(20.5)$ & $200(100)$ & & \\
\hline \multirow{3}{*}{ Sosyal medya } & Kent & $48(48)$ & $52(52)$ & $100(100)$ & & \\
\hline & Kırsal & $12(12)$ & $88(88)$ & $100(100)$ & 30.857 & $<0.001$ \\
\hline & Toplam & $60(30)$ & $140(70)$ & $200(100)$ & & \\
\hline \multirow{3}{*}{ Anlık mesaj } & Kent & $40(40)$ & $60(60)$ & $100(100)$ & & \\
\hline & Kirsal & $41(41)$ & 59 (59) & $100(100)$ & 0.021 & 0.885 \\
\hline & Toplam & $81(40.5)$ & $119(59.5)$ & $200(100)$ & & \\
\hline \multirow{3}{*}{ Müzik } & Kent & 39 (39) & $61(61)$ & $100(100)$ & & \\
\hline & Kirsal & $100(100)$ & $0(0)$ & $100(100)$ & 87.770 & $<0.001$ \\
\hline & Toplam & 139 (69.5) & $61(30.5)$ & $200(100)$ & & \\
\hline \multirow{3}{*}{ Video } & Kent & $52(52)$ & $48(48)$ & $100(100)$ & & \\
\hline & Kirsal & $61(61)$ & 39 (39) & $100(100)$ & 1.648 & 0.199 \\
\hline & Toplam & $113(56.5)$ & 87 (43.5) & $200(100)$ & & \\
\hline \multirow{3}{*}{ Oyun } & Kent & 57 (57) & $43(43)$ & $100(100)$ & & \\
\hline & Kırsal & $100(100)$ & $0(0)$ & $100(100)$ & 54.777 & $<0.001$ \\
\hline & Toplam & $157(78.5)$ & $43(21.5)$ & $200(100)$ & & \\
\hline \multirow{3}{*}{ Finansal } & Kent & $52(52)$ & $48(48)$ & $100(100)$ & & \\
\hline & Kirsal & $100(100)$ & $0(0)$ & $100(100)$ & 63.158 & $<0.001$ \\
\hline & Toplam & $152(76)$ & $48(24)$ & $200(100)$ & & \\
\hline \multirow{3}{*}{ Alışveriş } & Kent & $46(46)$ & $54(54)$ & $100(100)$ & & \\
\hline & Kırsal & $100(100)$ & $0(0)$ & $100(100)$ & 73.973 & $<0.001$ \\
\hline & Toplam & 146 (73) & $54(27)$ & $200(100)$ & & \\
\hline \multirow{3}{*}{ Diğer } & Kent & 97 (97) & $3(3)$ & $100(100)$ & & \\
\hline & Kirsal & $100(100)$ & $0(0)$ & $100(100)$ & 3.046 & 0.081 \\
\hline & Toplam & 197 (98.5) & $3(1.5)$ & $200(100)$ & & \\
\hline
\end{tabular}

\subsection{Kentsel ve Kırsal Alanda Cinsiyet Bazlı Karșılaștırmalar}

Çalışma yalnızca kent ve kır nüfusunu değil, aynı zamanda kırsal ve kentsel alanda yaşayan nüfusun BİT kullanımının cinsiyet bazında değişimini de incelenmiştir. Bir başka deyişle, kentsel alanda yaşayan kadınlar ile kırsal alanda yaşayan kadınlar arasında BİT kullanımı açısından farklılık olup olmadığını ve varsa bu farklılıkların hangi faktörler tarafindan ne yönde şekillendirildiğini belirlemek amaçlanmıştır. Ankete katılan kentsel ve kırsal alanda yaşayan kadın ve erkeklerin eğitim durumları incelenmiş ve Çizelge 6'da verilmiştir. 
Çizelge 6. Kentsel ve kırsal alanda yaşayan kadın ve erkeklerin eğitim durumları

Table 6. Distribution of respondents according to their level of formal education with gender and place to live

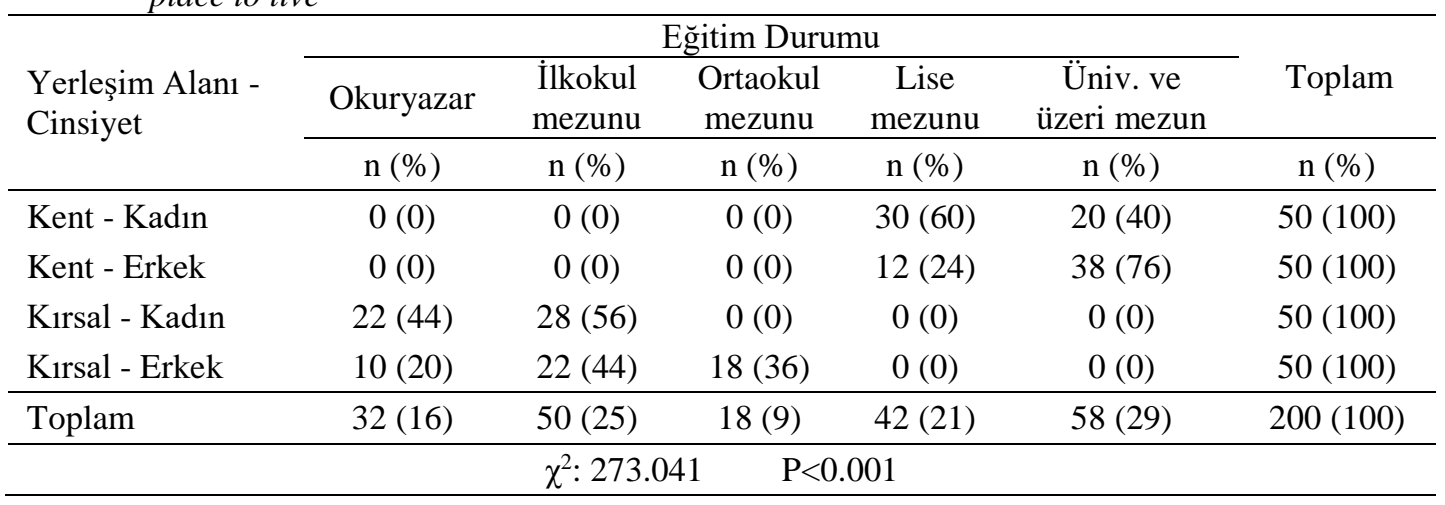

Kentsel ve kırsal alanda yaşayan nüfus arasında cinsiyetler arasında eğitim açısından önemli farklılıklar göze çarpmaktadır. Kentsel alanda yaşayan kadınların \%40'1 üniversite mezunu iken aynı alanda yaşayan erkek nüfusu içinde üniversite mezunu olanların oranı bunun yaklaşık iki katıdır (\%76). Kırsal alandaki kadın nüfusunun yarıya yakını okuryazar seviyesindedir. İlkokul mezunu kesim ancak \%56'dır. Erkek nüfusunun da ancak \%36’lık bir kısmı ortaokul mezunudur. Kirsal alanda yaşayan kadın ve erkekler arasında lise ve üzeri seviye eğitim alan kimse bulunmamaktadır. İstatistiksel analiz sonucu anlamlı farklılık olduğu tespit edilmiştir $(\mathrm{P}<0,001)$.

Ankete katılan kentsel ve kırsal alanda yaşayan kadın ve erkeklerin çalışma durumları incelenmiş ve Çizelge 7'de verilmiştir.

Çizelge 7. Kentsel ve kırsal alanda yaşayan kadın ve erkeklerin çalışma durumları Table 7. Distribution of respondents according to their employment status with gender and place to live

\begin{tabular}{|c|c|c|c|c|c|c|c|c|c|}
\hline \multirow{3}{*}{$\begin{array}{l}\text { Yerleşim Alanı - } \\
\text { Cinsiyet }\end{array}$} & \multicolumn{8}{|c|}{ Çalışma Durumu } & \multirow[b]{2}{*}{ 売 } \\
\hline & 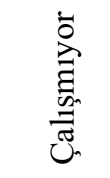 & $\begin{array}{l}\bar{\Xi} \\
\text { 志 } \\
\text { 至 } \\
\text { 至 }\end{array}$ & $\begin{array}{l}\overline{0} \\
\overline{0} \\
: 00 \\
: 0\end{array}$ & 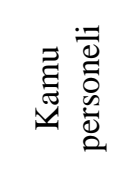 & 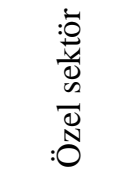 & 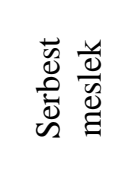 & 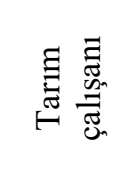 & 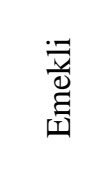 & \\
\hline & n (\%) & n (\%) & n (\%) & n (\%) & n (\%) & n (\%) & n (\%) & n (\%) & n (\%) \\
\hline Kent - Kadın & $4(8)$ & $5(10)$ & $10(20)$ & 7 (14) & $9(18)$ & $13(26)$ & $0(0)$ & $2(4)$ & $\begin{array}{c}50 \\
(100)\end{array}$ \\
\hline Kent - Erkek & $3(6)$ & $0(0)$ & $2(4)$ & $19(38)$ & $13(26)$ & 9 (18) & $0(0)$ & $4(8)$ & $\begin{array}{c}50 \\
(100)\end{array}$ \\
\hline Kırsal - Kadın & $5(10)$ & $31(62)$ & $0(0)$ & $0(0)$ & $13(26)$ & $0(0)$ & $0(0)$ & $1(2)$ & $\begin{array}{c}50 \\
(100)\end{array}$ \\
\hline Kırsal - Erkek & $0(0)$ & $0(0)$ & $0(0)$ & $0(0)$ & $2(4)$ & $0(0)$ & 47 (94) & $1(2)$ & $\begin{array}{c}50 \\
(100)\end{array}$ \\
\hline Toplam & $12(6)$ & $36(18)$ & $12(6)$ & $26(13)$ & 37 (19) & $22(11)$ & $47(24)$ & $8(4)$ & $\begin{array}{l}200 \\
(100)\end{array}$ \\
\hline
\end{tabular}

Kırsal alanda yaşayan nüfus ile kentsel alanda yaşayan nüfus arasında keskin bir ayrım bulunmaktadır. Kentsel alanda yaşayan nüfus içerisinde tarım çalışanı yoktur. Kırsal alanda yaşayan nüfusta da öğrenci, kamu personeli ve serbest meslek sahibi bulunmamaktadır. Cinsiyet bazında karşılaştıııldığında kentsel alanda yaşayan kadın nüfusunun yalnızca \%10'u ev hanımı iken kentsel alanda bu oran \%62'dir. Buna karşın kırsal alanda çalışmayan erkek yokken kentsel alanda \%6'lık bir erkek nüfusu çalışmamaktadır. Diğer yandan, kırsal alanda yaşayan kadın nüfusu içinde tarım çalışanı bulunmaması dikkat çekicidir. Bu nüfus ev hanımlığı dışında $\% 10$ oranında çalışmadığını, \%26 oranında da özel sektör çalışanı olduğunu ifade etmiştir. $\mathrm{Bu}$ durumda Arıkan (1988)'ın da belirtmiş olduğu gibi aile iş̧̧isi kadınların kendilerini tarım çalışanından çok ev hanımı olarak algılamaları söz konusu olabilir. İstatistiksel olarak cinsiyet bazında yaşanan bölgenin çalışma durumu ile anlamlı bir farklılık olduğu belirlenmiş $(\mathrm{P}<0,001)$. Ankete katılan kentsel ve kırsal 
alanda yaşayan kadın ve erkeklerin gelir durumları incelenmiş ve Çizelge 8'de verilmiştir.

Çizelge 8. Kentsel ve kırsal alanda yaşayan kadın ve erkeklerin gelir durumları

Table 8. Distribution of respondents according to their income levels with gender and place to live

\begin{tabular}{|c|c|c|c|c|c|}
\hline \multirow{3}{*}{$\begin{array}{l}\text { Yerleşim Alanı - } \\
\text { Cinsiyet }\end{array}$} & \multicolumn{4}{|c|}{ Gelir (TL) } & \multirow{2}{*}{ Toplam } \\
\hline & $1800-2500$ & $2501-5000$ & $5001-10000$ & $>10001$ & \\
\hline & $\mathrm{n}(\%)$ & n (\%) & n (\%) & n (\%) & n (\%) \\
\hline Kent - Kadın & $13(26)$ & $17(34)$ & $19(38)$ & $1(2)$ & $50(100)$ \\
\hline Kent - Erkek & $8(16)$ & $37(74)$ & $5(10)$ & $0(0)$ & $50(100)$ \\
\hline Kırsal - Kadın & $28(56)$ & $22(44)$ & $0(0)$ & $0(0)$ & $50(100)$ \\
\hline Kirsal - Erkek & $28(56)$ & $22(44)$ & $0(0)$ & $0(0)$ & $50(100)$ \\
\hline Toplam & 77 (39) & $98(49)$ & $24(12)$ & $1(1)$ & $200(100)$ \\
\hline$\chi^{2}: 69.075$ & \multicolumn{5}{|c|}{$\mathrm{P}<0.001$} \\
\hline
\end{tabular}

Kentsel alanda yaşayan kadınların \%72'si 2500-10000 TL arası gelire sahiptirler. Kırsal alanda yaşayan kadınlar arasında 5000 TL üzeri gelire sahip olan bulunmamaktadır. Ayrıca kırsal kesimde cinsiyetler arasında gelir açısından bir eşitlik gözlemlenmektedir. Oysa kentsel alanda ücret seviyesi yüksekliği açısından kadınlar lehine dengenin değiştiği gözlenmektedir. Cinsiyete göre yaşanan yerin gelir ile farklılığı istatistiksel olarak önemli bulunmuştur $(\mathrm{P}<0,001)$.

Ankete katılan kentsel ve kırsal alanda yaşayan kadın ve erkeklerin akıllı telefon kullanma durumları incelenmiş ve Çizelge 9'da verilmiştir.

Çizelge 9. Kentsel ve kırsal alanda yaşayan kadın ve erkeklerin akıllı telefon kullanım durumları

Table 9. Distribution of respondents according to their use of mobile phone with gender and place to live

\begin{tabular}{lccccc}
\hline \multirow{2}{*}{$\begin{array}{l}\text { Yerleşim Alanı - } \\
\text { Cinsiyet }\end{array}$} & \multicolumn{2}{c}{ Akıllı Telefon Kullanma Durumu } & Toplam & \multirow{2}{*}{$\chi^{2}$} & $\mathrm{P}$ \\
\cline { 2 - 3 } & Hayır & Evet & & & \\
\cline { 2 - 4 } & $\mathrm{n}(\%)$ & $\mathrm{n}(\%)$ & $50(100)$ & & \\
\hline Kent - Kadın & $2(4)$ & $48(96)$ & & & \\
Kent - Erkek & $1(2)$ & $49(98)$ & $50(100)$ & & \\
Kirsal - Kadın & $12(24)$ & $38(76)$ & $50(100)$ & 26.739 & $<0.001$ \\
Kirsal - Erkek & $0(0)$ & $50(100)$ & $50(100)$ & & \\
\hline Toplam & $15(7.5)$ & $185(92.5)$ & $200(100)$ & & \\
\hline
\end{tabular}

Kentsel alanda akıllı telefon kullanımında hem kadın hem de erkeklerin kullanım oranları çok yüksektir ve birbirine yakındır (erkek \%98 kadın \%96). Ancak kırsal kesimde erkek nüfusunun tamamı akıllı telefon kullanırken kadınların neredeyse dörtte biri akıllı telefon kullanmamaktadır. $\mathrm{Bu}$ eğilim kentte yaşayan kadın nüfusunda da, kırsalda yaşayan erkek nüfusunda da görülmemektedir. Dolayısıyla kırsalda yaşayan kadın nüfusuna özgü bir teknolojiye sahip olamama, kaçınma veya yeniliği reddetme eğilimi söz konusu olabilir. Eş deyişle, hem yaşanan bölge, hem de cinsiyete bağlı bir davranış söz konusu olabilmektedir. Cinsiyete bağlı olarak yaşanan bölgenin akıllı telefon kullanımı ile anlamlı bir istatistiksel farklılık gösterdiği belirlenmiş $(\mathrm{P}<0,001)$.

Ankete katılan kentsel ve kırsal alanda yaşayan kadınların bilgisayar kullanmama nedenleri incelenmiş ve Çizelge 10'da verilmiştir.

Çizelge 10. Kentsel ve kırsal alanda yaşayan kadınların internet kullanmama nedenleri Table 10. Distribution of women respondents according to their reasons for refusing internet with place to live

\begin{tabular}{|c|c|c|c|c|c|c|}
\hline \multirow{3}{*}{$\begin{array}{l}\text { Yerleşim Alanı - } \\
\text { Cinsiyet }\end{array}$} & \multicolumn{3}{|c|}{ İnternet kullanmama nedenleri } & \multirow[b]{2}{*}{ Toplam } & \multirow[b]{2}{*}{$\chi^{2}$} & \multirow[b]{2}{*}{$\mathrm{P}$} \\
\hline & Bütçem yok & $\begin{array}{l}\text { Zararlı olduğunu } \\
\text { düşünüyorum }\end{array}$ & Diğer & & & \\
\hline & n (\%) & $\mathrm{n}(\%)$ & n (\%) & n (\%) & \multirow{4}{*}{14.00} & \multirow{4}{*}{$<0.001$} \\
\hline Kent - Kadın & $1(50)$ & $0(0)$ & $1(50)$ & $2(100)$ & & \\
\hline Kırsal - Kadın & $0(0)$ & $12(100)$ & $0(0)$ & $12(100)$ & & \\
\hline Toplam & $1(7.1)$ & $12(85.7)$ & $1(7.1)$ & $14(100)$ & & \\
\hline
\end{tabular}


Kentsel ve kırsal alanda erkek nüfusunda internet kullanmayan katılımcıya rastlanmamıştır. Ancak kentsel alanda yaşayan kadın nüfusu içinde yalnızca bir katılımcı internet kullanmamakta ve bunun bütçe nedeni ile olduğunu ifade etmektedir. Oysa kırsal alanda yaşayan 12 kadın katılımeı interneti zararlı buldukları için kullanmadıklarını beyan etmişlerdir. Ortalama gelir seviyesi daha düşük olmasına rağmen kırsal alanda yaşayan kadın nüfusunun internet kullanımı için bütçelerinin bulunması dikkat çekicidir. Yaşanan bölgenin kadın nüfusunun internet kullanılmamasına bağımlılığı istatistiksel olarak anlamlı bulunmuştur $(\mathrm{P}<0,001)$.

Ankete katılan kentsel ve kırsal alanda yaşayan erkek ve kadınların karşılaştırmalı finans amaçlı internet kullanım durumları da incelenmiş ve Çizelge 11'de verilmiştir.

Çizelge 11. Kentsel ve kırsal alanda yaşayan kadın ve erkeklerin finans amaçlı internet kullanım durumları Table 11. Distribution of respondents according to their financial use of internet with gender and place to live

\begin{tabular}{|c|c|c|c|c|c|}
\hline \multirow{3}{*}{$\begin{array}{c}\text { Yerleşim Alanı - } \\
\text { Cinsiyet }\end{array}$} & \multicolumn{2}{|c|}{ Finans amaçlı internet kullanım durumları } & \multirow{2}{*}{ Toplam } & \multirow{3}{*}{$\chi^{2}$} & \multirow{3}{*}{$\mathbf{P}$} \\
\hline & Hayır & Evet & & & \\
\hline & $\mathrm{n}(\%)$ & $\mathrm{n}(\%)$ & $\mathrm{n}(\%)$ & & \\
\hline Kent - Kadın & $27(54)$ & $23(46)$ & $50(100)$ & & \\
\hline Kent - Erkek & $25(50)$ & $25(50)$ & $50(100)$ & & \\
\hline Kırsal - Kadın & $50(100)$ & $0(0)$ & $50(100)$ & 63.377 & $<0.001$ \\
\hline Kirsal - Erkek & $50(100)$ & $0(0)$ & $50(100)$ & & \\
\hline Toplam & $152(76)$ & $48(24)$ & $200(100)$ & & \\
\hline
\end{tabular}

Finansal amaçlarla internet kullanımı (para transferi, ödeme yapma, vb.) açısından kırsal ve kentsel alanlar arasında büyük farklılık bulunmaktadır. Kırsal kesimde yaşayan nüfusun tamamı finansal işler için internet kullanımından kaçınmaktadır. Oysa kentsel alanda yaşayan nüfusun kadınlarda da erkeklerde de yarıya yakını finansal amaçlarla internet kullanımı gerçekleştirmektedir. Aradaki farklılık istatistiksel olarak anlamlı bulunmuştur $(\mathrm{P}<0,001)$. Ankete katılan kentsel ve kırsal alanda yaşayan erkek ve kadınların alışveriş amaçlı internet kullanım durumları incelenmiş ve Çizelge 12 'de verilmiştir.

Çizelge 12. Kentsel ve kırsal alanda yaşayan kadın ve erkeklerin alışveriş amaçlı internet kullanım durumları Table 12. Distribution of respondents according to their internet us for shopping with gender and place to live

\begin{tabular}{|c|c|c|c|c|c|}
\hline \multirow{3}{*}{$\begin{array}{r}\text { Yerleşim Alanı - } \\
\text { Cinsiyet }\end{array}$} & \multicolumn{2}{|c|}{ Alışveriş amaçlı internet kullanım durumları } & \multirow{2}{*}{ Toplam } & \multirow{3}{*}{$\chi^{2}$} & \multirow{3}{*}{$\mathbf{P}$} \\
\hline & Hayır & Evet & & & \\
\hline & $\mathrm{n}(\%)$ & $\mathrm{n}(\%)$ & n (\%) & & \\
\hline Kent - Kadın & $26(52)$ & $24(48)$ & $50(100)$ & & \\
\hline Kent - Erkek & $20(40)$ & $30(60)$ & $50(100)$ & & \\
\hline Kırsal - Kadın & $50(100)$ & $0(0)$ & $50(100)$ & 75.799 & $<0.001$ \\
\hline Kirsal - Erkek & $50(100)$ & $0(0)$ & $50(100)$ & & \\
\hline Toplam & $146(73)$ & $54(27)$ & $200(100)$ & & \\
\hline
\end{tabular}

Katılımcıların alıșveriş amaçlı internet kullanım eğilimleri finansal amaçlı internet kullanımındaki gibi olduğu belirlenmiştir. Kentte yaşayan kadın ve erkek nüfusun yarısından fazlası alışveriş amacıyla internet kullanırken kırsal alanda bu amaçlı kulanım oranı sıfirdır. Dolayısıyla kırsal kesim nüfusunun cinsiyetten bağımsız olarak internet üzerinden alışverişten kaçınma/reddetme eğilimleri söz konusudur. $\mathrm{Bu}$ konudaki davranışın interneti finansal amaçlarla kullanma eğilimi konusundaki davranışla paralelliği dikkat çekicidir. Aradaki paralellik nedeni ile eldeki verilere dayanarak kırsal kesim nüfusunun parasal konular ve internet kavramları arasına bir duvar çektiği söylenebilir. Bu durumdaki farkl1lık istatistiksel olarak anlamlı bulunmuştur $(\mathrm{p}<0,01)$.

\section{Sonuçlar}

$\mathrm{Bu}$ çalışmada Ankara ili örneği çerçevesinde kırsal ve kentsel alanlarda yaşayan kadın ve erkek nüfusunun BİT kullanımları incelenmiştir. Daha açık bir ifade ile yaşanılan bölgenin kırsal veya kentsel olmasının cinsiyet bazında BİT araçlarını kullanma durumu, sıklığı ve kullanım amaçları analiz edilmiştir. Araştırma sonuçlarına göre kırsal kesim ve kentsel alanda yaşayan nüfus arasında belirlenmiş eğitim seviyesi farklılığının BİT kullanımında etken olduğu düşünülmektedir. Her ne kadar bu farklılık kırsal kesim nüfusunun BİT kullanımını tamamen engellemese bile belirli açılardan kullanım seviyesini olumsuz etkilemektedir. 
Araştırmada elde edilen bulgular, çalışmanın gerçekleştirildiği alanda kırsal kesimde yaşayan nüfusun kent nüfusuna göre daha az BİT aracına sahip olduğuna işaret etmektedir. Başkent Ankara'ya yaklaşık bir saat mesafede olan kırsal alanda dahi kablonet veya ADSL gibi karasal altyapı yokluğu nedeniyle bu teknolojiler kullanılmamakta, ağırlıklı olarak mobil teknolojiler kullanılmaktadır. Diğer yandan, kırsal alanda yaşayan nüfusun kentsel nüfusa göre daha düşük olan ortalama gelir seviyesi de daha bilinçli harcama eğilimlerine yol açtı̆̆ için kentsel nüfusun yatırım yapabildiği bilgisayar gibi BİT araçlarına kırsal nüfusun ilgi göstermemesi de bu konuda bir etkendir. Bu nedenle hem evde hem arazide veya başka yerlerde kullanabilecekleri rahat ve pratik araçlar olan cep telefonlarına yatırım açısından kent ve kırsal arasında fark gözlemlenmemiştir.

Diğer yandan, geçerli teknoloji seviyesini temsil eden akıllı telefonlar konusunda kent ve kır arasinda fark tespit edilmiştir. Kentsel ve kırsal alanda yaşayan erkek nüfusunun yaklaşık aynı oranda akıllı telefon kullanmasına, kentsel alanda yaşayan kadın nüfusunun da yaklaşık olarak bu oranda akıllı telefon kullanımı gerçekleştirmesine rağmen kırsalda yaşayan kadın nüfusunun yaklaşık dörtte biri akıllı telefon kullanmamaktadır. Oysa bu nüfus cep telefonu kullanmaktan çekinmemektedir.

Buradaki anahtar ilişki, akıllı telefon kullanmayan kırsal kesimde yaşayan kadın oranı ile internetin zararlı olduğunu düşünen kadın sayısı arasındadır. Ankete katılan ve kırsal kesimde yaşayıp akıllı telefon kullanmayan kadınlar neden olarak interneti zararlı buldukları için kullanmadıklarını belirtmişlerdir. İncelendiğinde, kırsal kesim erkek nüfusunun interneti zararlı bulmasa dahi benzer çekincelere sahip oldukları görülebilir. Kırsal kesimde yaşayan erkekler de kadınlar da BİT araçlarını genelde anlık ve nispeten zararsız olarak düşünülebilecek video izleme, anlık mesajlaşma ve sosyal medyayı takip etme gibi amaçlar doğrultusunda kullanmaktadırlar. Oysa kentsel nüfusun rahatlıkla kullandığı finansal amaçlar ve alışveriş gibi konularda kırsal kesimdeki kullanım oranı neredeyse sıfirdır. Dolayısı ile parasal olarak zarara uğrayabilecekleri konularda BİT araçlarına bir güvensizlik söz konusudur.

$\mathrm{Bu}$ değerlendirmeler sonucunda kırsal alanda yaşayan nüfusun kentsel alana göre daha az BİT aracı kullandığı ve genel olarak daha kısıtlı amaçlar doğrultusunda BİT kullanımı gerçekleştirdiği söylenebilir. Dolayısı ile Hipotez 1 doğrulanmıştır. Aynı zamanda kırsal alanda yaşayan kadın nüfusunun BİT kullanımının gerek kentsel alanda yaşayan kadın nüfusuna, gerekse de kırsal alanda yaşayan erkek nüfusuna göre daha az BİT aracı kullanarak ve daha kısıtlı amaçlarla BİT'ten faydalanarak daha düşük seviyede gerçekleştiği de belirlenmiş, böylece Hipotez 2 ve Hipotez 3'de doğrulanmışlardır.

Ancak bulgular kentsel alanda yaşayan nüfus cinsiyet ayrımında değerlendirildiğinde erkek ve kadın nüfusunun BİT araçlarının gerek çeşitlilik gerekse kullanım amacı açısından farklılık göstermediğini ortaya koymaktadır. Eş deyişle, kentsel alanda yaşayan erkek ve kadınların kullandıkları BİT araçları da bunları kullanım amaçları da birbirine yakındır. Dolayısı ile söz konusu Hipotez 4 reddedilmiştir. Bunun anlamı, BİT kullanım eğilimlerini cinsiyet faktörünün tek başına belirlemediğidir.

BİT'in kırsal kesim kadın nüfusunda daha yaygın ve etkin kullanımı açısından ele alınabilecek faktörler arasında ilk olarak eğitim faktörü akla gelmektedir. Ancak ankete verilen yanıtlar bu düşünceyi doğrulamamaktadır. Kırsal kesimde yaşayan kadın nüfusu, eğitim seviyesi kentsel alana göre düşük olsa da BİT araçlarını kullanamıyor değildir. Ayrıca interneti daha çok kullanmak için sunulan seçenekler arasında bulunan eğitim seçeneğini seçmemişlerdir. Kırsal alanda yaşayan kadınların interneti kullanma, kullanan kesimin de daha etkin şekilde faydalanmasını sağlayacak faktör internet üzerinden yapılan işlemlere olan güven algılarının artırılması gerekmektedir. Daha açık bir ifadeyle internet üzerinden alışveriş, fatura ödeme ve para transferi gibi dijital işlemlere olan kırsal kesimdeki olumsuz tutumun giderilmesi önem taşımaktadır.

Bütün bunlar göz önüne alındığında yalnızca günlük işlemlerin dahi kırsal kesim nüfusunun hayatını kolaylaştıracağ 1 açıktır. Halen daha ürününü satmak için pazara giden, girdi tedarik etmek ya da ödeme yapmak için yakındaki ilçe veya şehre gitmek zorunda kalan kırsal nüfus bu olanaklardan faydalanırsa hem yolda harcanan zaman, işgücü ve maliyetten tasarruf edilebilecek, hem de çevrim içi satış ekonomisindeki rekabet nedeni ile ihtiyaçlarını çok daha ucuza karşılarken özellikle hacimli veya ağır malzemelerin nakliye maliyetini de en aza indirmiş olacaktır. Öte yandan medya okuryazarlı̆̆ eğitimleri sonucu dijital pazarlama aracılığıyla kırsal kesimde yaşayanların ürünlerin yeni pazarlara daha yüksek fiyatlardan satmaları mümkün olabilecektir.

Ancak bu belirtilenler BİT'in kırsal kesim nüfusuna sağlayabileceği faydaların en azıdır. Kırsal kesim nüfusu, özellikle de aile iş̧̧isi statüsündeki kadın nüfusu, çeşitli otomasyon ve izleme sistemlerini kullanarak üretim verimliliğini de, üretimde harcanan işgücü verimliliğini de arttırabilirler. Örneğin ürün sulamayı kurala veya deneyime bağlı gerçekleştirmek yerine toprak iletkenliğini ölçen sensörler vasıtasıyla otomatik olarak ve ancak yeterli olacak ölçüde gerçekleştirerek hem üretim giderlerini hem de iş gücü maliyetini optimize edebilirler. Hayvancılıkla uğraşan kesim mera denetimini drone ile hizlı ve rahat bir şekilde gerçekleştirirken ağıl, ahır, kümes gibi yerlerin güvenliğini hatta girdi kullanımı ve bakım işlerini bu kamera, sensorlar ve otomasyon araçları ile sağlayabilirler. Üstelik bu tür sistemlerin kurulumu için gerekli donanım ve hizmeti aramak için yalnızca hâlihazırda kullandıkları akıllı cihazları kullanmaları 
yeterli olacaktır. İstenirse bahsedilen sistemlerin kullanımı dahi bu cihazlar üzerinden gerçekleştirilebilir.

$\mathrm{Bu}$ teknolojik ilerlemelerin yaygınlaşması ile dijital tarım üzerine araştırma, geliştirme, eğitim, yayım ve danışmanlık hizmetlerinin artması ve firmaların gelişmesidir. Bu kurum ve firmaların artan talep üzerine yerel teknolojileri geliştirmesi, dolayısıyla Türkiye ekonomisinin tarım teknolojileri konusunda dışa bağımlılığını azaltacak ve tarımda verimliliğgi arttıracaktır. Geliştirilen teknolojilerin ihracatı ile döviz geliri sağlanabilecektir. Tüm bunların gerçekleşebilmesi için kırsal kesim nüfusunun BİT kullanımının yaygınlaştırılması gerekmektedir.

\section{Teşekkür}

Alan çalışmaları sırasında anket çalışmalarına katılan tüm katılımcılara çok teşekkür ederiz. Çalışmanın planlanması ve verilerin analiz aşamalarında yardımlarından dolayı Dr. Nur İlkay Abacı ve Dr. Hasan Samet Abacı'ya teşekkürü borç biliriz.

\section{Kaynaklar}

Abacı, N. İ., ve Demiryürek, K. 2015. Türkiye de Kırsal Alanlarda Bilgi İletişim Teknolojilerinin Kullanım Durumu. İç Anadolu Bölgesi 2. Tarım ve Gıda Kongresi, NEVŞEHIR.

Abbate, J. 2000. Inventing the Internet. MIT Press, 4382, Cambridge, Massachusetts.

Akar, F. 2015. Purposes, Causes and Consequences of Excessive Internet Use among Turkish Adolescents. Eurasian Journal of Educational Research, 15:60, 35-56.

Almina. 2017. Türkiye'de İlk Radyo Yayınından Bugüne. Radyo Dinle. http://www.radyoyayini.org/genel/turkiyede-ilkradyo-yayinindan-bugune.html (Erişim tarihi: 14.07.2018)

Anonim, 2017a. Türkiye'de televizyon. Vikipedi. https://tr.wikipedia.org/wiki/T\%C3\%BCrkiye\%27de _televizyon (Erişim tarihi: 6.10.2018)

Anonim, 2017b. Gelir ve Yaşam Koşulları Araştırması, 2016. Türkiye İstatistik Kurumu. https://www.tuik.gov.tr/PdfGetir.do?id=24579 (Erişim tarihi: 11.07.2019)

Anonim, 2017c. Asgari Ücretin Net Hesab1 ve İşverene Maliyeti. Aile, Çalışma ve Sosyal Politikalar Bakanlığı.

https://ailevecalisma.gov.tr/media/1234/2016_onikia y.pdf (Erişim tarihi: 25.06.2019)

Anonim, 2018a. Kırsal Kalkınma Özel İhtisas Komisyon Raporu. http://www.sbb.gov.tr/wpcontent/uploads/2020/04/KirsalKalkinmaOzelIhtisas KomisyonuRaporu.pdf (Erişim tarihi 06.07.2020)

Anonim 2018b. Kırsal Alanda Kadının Güçlendirilmesi ve Kırsalda Kadın Girişimciliğinin Desteklenmesi Konulu Komisyon Raporu (Yayın No. 21). TBMM
Basımevi, Ankara. https://komisyon.tbmm.gov.tr/ dosyalar/KIRSAL\%20ALANDA\%20KADININ\%2 0G\%C3\%9C\%C3\%87LEND\%C4\%B0R\%C4\%B0L MES\%C4\%B0\%20RAPORU.pdf (Erişim tarihi: 03.07.2019)

Arıkan, G. 1988. Kırsal Kesimde Kadın Olmak. Hacettepe Üniversitesi Edebiyat Fakültesi Dergisi, 5:2, 1-16. https://dergipark.org.tr/download/articlefile/597771 (Erişim tarihi: 11.04.2019)

Cinemre, H.A. ve Demiryürek, K. 2005. Tarımsal Yayım ve Haberleşme Kitabı. Ondokuz Mayıs Üniversitesi Ziraat Fakültesi Ders Kitabı No: 17, Beşinci Baskı. Samsun https:// www.researchgate.net/ publication / 267394599 Tarimsal Yayim ve Haberlesme Kitabi (Erişim tarihi:07.07.2020).

Cukur, T. 2013. Determination of communication behavior of earthen pond fish farmers. Bulgarian Journal of Agricultural Science, 19(6), 1358-1363.

Demiryürek, K. 1993. Televizyon ile Yaygın Çiftçi Eğitimi Projesi (YAYÇEP)'ne Gölbaşı İlçesinde Çiftçilerin Katılımı Üzerine Bir Araştırma. Ankara Üniversitesi Fen Bilimleri Enstitüsü Yüksek Lisans Tezi.

Demiryürek, K. 2015. Yayım Sözlüğü. Gıda, Tarım ve Hayvancılık Bakanlığ 1 (GTHB). Tarımsal Ekonomi ve Politika Geliştirme Enstitüsü Müdürlügüü (TEPGE).Ankara./www.researchgate.net/publication /279528766 Yayim Sozlugu Dictionary of Extension Science in Turkish with English Abstract and Terms (Erişim tarihi: 07.07.2020).

Demiryürek, K., Abaci, N. İ., Abaci, S. H., Atasever, S., and Erdem, H. 2017. Effect of Dairy Cattle Breeders' Association (DCBA) Membership on Sustainability of Innovations in Samsun Province of Turkey. Custos e Agronegócio, 13:2, 35-44. https://www.researchgate.net/publication/320855059 (Erişim tarihi: 19.06.2019)

Demiryürek, K., and Atsan, T. 2015. Distance Education through Television for Farmers in Developing Countries the Case of Turkey. Anthropologist, 21(3), 374-379.

Gül, D. 2019. Kırsal ve kentsel alanda bilgi ve iletişim teknolojilerinin kullanım durumu: Ankara örneği. Ondokuz Mayıs Üniversitesi, Fen Bilimleri Enstitüsü, Tarım Ekonomisi AD Yüksek Lisans Tezi (Yayınlanmamış). Samsun.

Özaydınlık, K. 2014. Toplumsal Cinsiyet Temelinde Türkiye'de Kadın ve Eğitim. Sosyal Politika Çalışmaları Dergisi, 4:33, 93-112. doi:10.21560/spcd.03093

Özçağlar, A. (2016). Büyükşehir Belediyeli İllerde Kır ve Kent Nüfusunun Tespiti Mümkün mü? TÜCAUM Uluslararası Coğrafya Sempozyumu, 1314 Ekim, Bildiriler Kitabı, 271-291, Ankara.

Rogers, E. M. 1993. Diffusion of Innovations, Free Press, New York. 
Salemink, K., Strijker, D., and Bosworth, G. 2015. Rural development in the digital age: A systematic literature review on unequal ICT availability, adoption, and use in rural areas. Journal of Rural Studies, 54:2017, 360-371.

Tavşancil, E., Keser, H. 2002. Development of a Likert Type Attitude Scale towards Internet Usage. Journal of Educational Sciences and Practices, 1:1, 80-100.

TÜIK, $2018 . \quad$ Kır-Kent Tanımı. www.resmiistatistik.gov.tr (Erişim Tarihi: 25.02.2018).

TÜİK, 2019a. Hanehalkı Bilişim Teknolojileri Kullanım Araştırması. Türkiye İstatistik Kurumu: http://www.tuik.gov.tr/PreTablo.do?alt_id=1028 (Erişim tarihi: 08.01.2019)

TÜİK, 2019b. Yıllara ve Cinsiyete Göre İl / İlçe Merkezleri ve Belde / Köy Nüfusu, Genel Nüfus Sayımları - ADNKS. Türkiye İstatistik Kurumu: http://www.tuik.gov.tr/PreIstatistikTablo.do?istab_id $=1587$ (Erişim tarihi: 08.01.2019)

UNESCO, 2019. Information and communication technologies (ICT). UNESCO: http://uis.unesco.org/ en/glossary-term/information-and-communicationtechnologies-ict (Erişim tarihi: 08.01.2019)

Ursavaş, Ö. F. 2015. An examination of gender effect on pre-service teachers' behavioural intentions to use ICT. Journal of Theory and Practice in Education, 11:1, 68-88. acikerisim.lib. comu.edu.tr:8080/xmlui/bitstream/handle/COMU/10 57/\%C3\%96mer_Ursava\%C5\%9F_Makale.pdf?sequ ence $=1$ andisAllowed $=y$ (Erişim tarihi: 06.05.2019) 